\title{
Innovative partnerships to advance public health training in community-based academic residency programs
}

This article was published in the following Dove Press journal:

Advances in Medical Education and Practice

5 October 2017

Number of times this article has been viewed

\begin{abstract}
Joan C Lo ${ }^{1-3}$,
Thomas E Baudendistel ${ }^{2,3}$,

Abhay Dandekar ${ }^{3,4}$, Phuoc V Le ${ }^{5}$, Stanton Siu ${ }^{2,3}$, Bruce Blumberg 6

'Division of Research, Kaiser Permanente Northern California, Oakland, CA, USA; ${ }^{2}$ Department of Medicine, Kaiser Permanente Oakland Medical Center, Oakland, CA, USA; ${ }^{3}$ Graduate Medical Education, Kaiser Permanente East Bay, Oakland, CA, USA; ${ }^{4}$ Department of Pediatrics, Kaiser Permanente Oakland Medical Center, Oakland, CA, USA; ${ }^{5}$ School of Public Health, University of California Berkeley, Berkeley, CA, USA; ${ }^{6}$ Graduate Medical Education, Kaiser Permanente Northern California, Oakland, CA, USA
\end{abstract}

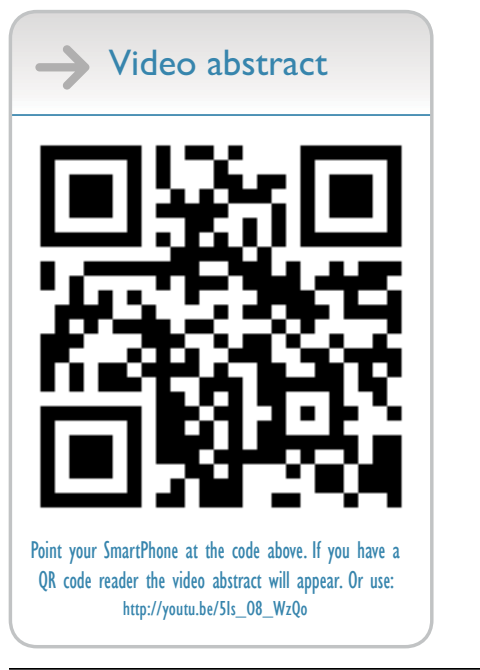

Correspondence: Joan C Lo Division of Research, Kaiser Permanente Northern California, 2000 Broadway,

Oakland, CA 94612, USA

Tel + I 5108913492

$\mathrm{Fax}+15108913508$

Email Joan.C.Lo@kp.org
Abstract: Collaborative partnerships between community-based academic residency training programs and schools of public health, represent an innovative approach to training future physician leaders in population management and public health. In Kaiser Permanente Northern California, development of residency-Masters in Public Health (MPH) tracks in the Internal Medicine Residency and the Pediatrics Residency programs, with MPH graduate studies completed at the University of California Berkeley School of Public Health, enables physicians to integrate clinical training with formal education in epidemiology, biostatistics, health policy, and disease prevention. These residency-MPH programs draw on more than 50 years of clinical education, public health training, and health services research - creating an environment that sparks inquiry and added value by developing skills in patient-centered care through the lens of population-based outcomes.

Keywords: graduate medical education, public health, master's degree, internal medicine, pediatrics, residency training

\section{Perspective}

In 1942, the first Kaiser Permanente hospital opened its doors in Oakland, California, providing medical care to workers and their families. ${ }^{1,2}$ By 1945 , the prepaid system of medical care known as the Permanente Plan opened to the general public, including individuals in the community and groups under a single employer. ${ }^{3}$ Medical education was part of the original vision, ${ }^{4,5}$ resulting in the 1946 establishment of the Kaiser Permanente Oakland Internal Medicine Residency by Dr Morris Collen, ${ }^{5}$ who was subsequently recognized internationally for his pioneering work in medical informatics and computerized medicine at the Kaiser Permanente Northern California Division of Research, which he established in $1961 .^{5-8}$ As Kaiser Permanente entered a period of substantial membership growth in this early era, both research and educational programs remained an established priority - important for stimulating both high quality of care and the advancement of medicine. ${ }^{4}$ Medical school affiliation or academic affiliation through master's degree training during residency was also considered during these formative years, but turned out not to be possible due to external logistic challenges. $^{4-6}$ Today, Kaiser Permanente has emerged as a leader in population health, with Kaiser Permanente Northern California serving four million individuals within an integrated health care delivery system. The number of Kaiser Permanente-sponsored training programs in Northern California has also expanded, ${ }^{9,10}$ and now includes a total of 17 residency and fellowship programs which train 289 residents and fellows 
annually. In 2016, the Kaiser Permanente Oakland Internal Medicine Residency Program celebrated its $70^{\text {th }}$ anniversary and the Pediatric Residency Program will celebrate its $60^{\text {th }}$ anniversary this year in 2017.

In the past 70 years, dramatic changes have occurred in the field of medicine, including medical discovery, innovations, disease prevention, and population health improvements. In 1946, the School of Public Health at the University of California Berkeley became the first school of public health west of the Mississippi to be accredited by the American Public Health Association. ${ }^{11}$ Since that time, many universitybased public health training programs have been established across the mid-west and west coast regions. As health care practice entered the $21^{\text {st }}$ century, Kaiser Permanente Northern California graduate medical education leaders recognized the need for newer residency education models to prepare the next generation of physicians to care for patients within the broader context of public health. With this in mind, regional leadership in conjunction with the categorical Internal Medicine Residency and Pediatric Residency programs at Kaiser Permanente Oakland Medical Center revisited the model of university partnership and successfully collaborated with the University of California Berkeley School of Public Health to develop separate Internal Medicine-Masters in Public Health (MPH) and Pediatrics-MPH residencies (Table 1), with the express goal of combining medical training and real world clinical practice with formal public health education to equip residents to become physician leaders in public health. Supported also by funding from the Kaiser Permanente Northern California Community Benefit Program (including full financial coverage of the MPH training year), each residency-MPH track now matches two medical students per year through the National Residency Match Program.

The combined Internal Medicine-MPH and PediatricMPH programs draw on over 50 years of education, health services research, and clinical experience, providing residents with 3 years of clinical training and opportunities for research, quality improvement, and medical education initiatives followed by the MPH year. Retention rates within the program have been extremely high, since medical students select the residency-MPH track during the residency application process and also provide a statement of purpose,

Table I Curricular examples of the Internal Medicine-MPH and Pediatrics-MPH residency training programs

\begin{tabular}{|c|c|c|}
\hline & Internal Medicine-MPH residency program & Pediatrics-MPH residency program \\
\hline \multirow{2}{*}{$\begin{array}{l}\text { Postgraduate } \\
\text { year I }\end{array}$} & Internal Medicine Internship & Pediatrics Internship \\
\hline & \multicolumn{2}{|c|}{$\begin{array}{l}\text { Annual Faculty and Resident Conference with UC Berkeley Interdisciplinary MPH faculty } \\
\text { Initiate faculty-mentored opportunities in research, quality improvement, innovation, and/or medical education* }\end{array}$} \\
\hline \multirow[t]{2}{*}{$\begin{array}{l}\text { Postgraduate } \\
\text { year } 2\end{array}$} & $\begin{array}{l}\text { Internal Medicine Residency } \\
\text { Integrated patient safety QI project and hospital rounds* }\end{array}$ & $\begin{array}{l}\text { Pediatrics Residency } \\
\text { External 3-year community immersion experience* }\end{array}$ \\
\hline & \multicolumn{2}{|c|}{$\begin{array}{l}\text { Annual Faculty and Resident Conference with UC Berkeley Interdisciplinary MPH faculty } \\
\text { Rotations at affiliated global health sites and other clinical sites (available to all KP Oakland residents)* }\end{array}$} \\
\hline \multirow[t]{2}{*}{$\begin{array}{l}\text { Postgraduate } \\
\text { year } 3\end{array}$} & $\begin{array}{l}\text { Internal Medicine Residency } \\
\text { Safety net public health clinic rotations in diverse settings* }\end{array}$ & $\begin{array}{l}\text { Pediatrics Residency } \\
\text { California legislative advocacy and policy rotation* }\end{array}$ \\
\hline & \multicolumn{2}{|c|}{$\begin{array}{l}\text { Annual Faculty and Resident Conference with UC Berkeley Interdisciplinary MPH faculty } \\
\text { Health policy elective and other clinical or subspecialty rotation opportunities relevant to future career goals* }\end{array}$} \\
\hline \multirow[t]{3}{*}{$\begin{array}{l}\text { Postgraduate } \\
\text { year } 4\end{array}$} & \multicolumn{2}{|c|}{$\begin{array}{l}\text { University of California Berkeley School of Public Health Interdisciplinary MPH program } \\
\text { Curricular schedule: summer (4-9 units), fall (17-19 units), spring (I7-19 units), 9-month MPH project } \\
\text { Unique aspects of the accelerated II-month Interdisciplinary MPH program: } \\
\text { > individual mentoring of mature scholars with diverse backgrounds and specific public health career goals; } \\
\text { > seminar-based learning and interdisciplinary focus on complex issues and challenges in public health; } \\
\text { > build skills to design and implement a project addressing public health challenges; } \\
\text { > gain experience in collaborating with community-based public health organizations; } \\
\text { > strong program leadership with extensive expertise in public health, health disparities and implementation }\end{array}$} \\
\hline & \multicolumn{2}{|c|}{$\begin{array}{l}\text { The residency-MPH year-long project can focus on a variety of public health topics, with past examples that include: } \\
\text { nutrition education, geriatric nutritional health, food security in vulnerable populations, health care reform, cardiac emergency } \\
\text { medical services, medication adherence, substance use, state vaccination policies, diabetes risk in youth, health needs } \\
\text { assessment in the juvenile justice system, housing for homeless youth, and sports-related concussion }\end{array}$} \\
\hline & \multicolumn{2}{|c|}{ A wide range of clinical experiences are available in postgraduate year 4 , including opportunity for clinical leadership } \\
\hline
\end{tabular}

Note: *Available to all categorical or MPH track residents within the residency training program.

Abbreviations: MPH, Masters in Public Health; KP, Kaiser Permanente; QI, quality improvement; UC, University of California. 
curriculum vitae, and educational training history for review by School of Public Health faculty. Because the residencyMPH programs are separately matched residency tracks, the selection process unfortunately does not accommodate categorical residents who later in the course of training decide to pursue an MPH degree.

During the first 3 years, residents complete their clinical training in Accreditation Council for Graduate Medical Education approved residency programs. Public health experiences are introduced early, through broader involvement of both categorical-track and MPH-track residents in community and global health opportunities and health policy rotations. The pediatrics program also focuses on resident development of longitudinal community partnerships. Opportunities in clinical research for both programs are emphasized, with additional support provided through Graduate Medical Education and the Division of Research. For internal medicine, joint appointment of residency-MPH program leadership with the Division of Research also increased research and scholarly activity for the entire Internal Medicine Residency (increasing from 9 journal publications over 5 years to 26 journal publications over 5 years). As such, the MPH tracks have been a catalyst for enhancing resident and faculty scholarly productivity, community engagement, and public service for the entire training program, where focused efforts by regional and program leadership to expand clinical research, exposure to health policy, and community outreach have benefited all residents.

The fourth and final year of training (following graduate program admission) includes the accelerated 11-month Interdisciplinary residency-MPH program at the University of California Berkeley, where residents have the opportunity to learn from and collaborate with world class public health faculty. The Interdisciplinary MPH includes a year-long project relevant to public health, health policy, disease prevention, disparities, clinical epidemiology, or initiatives at the county, state, federal, or international levels. These MPH projects have typically focused on health care-related issues directly relevant to the local San Francisco Bay area community (Table 1). The small class size, curricular diversity, close mentoring, and seminar-based approach of the Interdisciplinary MPH year enables residents to shape their educational experience and strategically align their coursework and project(s) with future career goals.

Keys to the operational success of these programs have included the collaboration of Kaiser Permanente Northern California graduate medical education leadership with the University of California Berkeley School of Public Health
(Interdisciplinary MPH program) leadership, the recruitment of Assistant Program Directors to oversee the residency-MPH tracks and facilitate both faculty and peer mentorship, and the integration of the MPH pathway with residency training, rather than just an additional year of education. This supplemental experience cultivates an intentional and progressively building sense of prevention-focused problem solving in the clinical learning environment which relates to all areas of competency. For these trainees and their colleagues, the anticipation of public health immersion also sparks inquiry, deliberate attention, and added value by developing skills in patient-centered care through the lens of population-based outcomes. Perhaps the greatest realization of success comes from the 16 residency-MPH graduates themselves, who have gone on to successful faculty and practice careers in university partnership settings serving multicultural populations, specialty care of older adults, community and public health clinics, global health, and integrated health care delivery systems such as Kaiser Permanente, including both primary care and hospital-based medicine. A major focus of these practice-based settings includes disease prevention, public and population health, and efforts to reduce health disparities. While it is too early to quantify the full impact of integrating public health with clinical training, future metrics should include ascertainment of professional products resulting from the residency-MPH programs.

In summary, collaborative partnerships between community-based academic programs and schools of public health represent an innovative approach to training future physician leaders in population management and public health, while benefiting the entire residency program, institution, and surrounding population. This halo effect is consistent with the larger Kaiser Permanente mission of meeting and serving the needs of the local community, where the university partnership, originally envisioned more than 50 years ago, is now focused on $21^{\text {st }}$ century public health.

\section{Acknowledgment}

This paper was presented as a poster at the California's Macy Regional Conference on Innovations in Graduate Medical Education: Building a Better Workforce for Better Health on March 30, 2016 in San Francisco, CA, USA.

\section{Disclosure}

The authors report employment by The Permanente Medical Group (JCL, TEB, AD, SS, and BB) or the University of California Berkeley (PVL); and support of the Kaiser Permanente Northern California Residency Programs by the 
Kaiser Foundation Hospitals Health Plan and the Kaiser Permanente Northern California Community Benefit Program. The authors report no other conflicts of interest in this work.

\section{References}

1. [No authors listed]. Bob Hughes, editor. KP Reporter. August 1967; 10(7):1.

2. Cushing L. Kaiser Permanente. A history of total health: Permanente Oakland Hospital - pride in service; 2014. Available at: http://kaiserpermanentehistory.org/latest/permanente-oakland-hospital-pride-inservice/. Accessed January 1, 2017.

3. Cushing L. Kaiser Permanente $A$ history of total health: opening the Permanente plan to the public; 2015. Available at: http://kaiserpermanentehistory.org/latest/opening-the-permanente-plan-to-the-public/. Accessed January 1, 2017.

4. Debley T, Stewart J. The Story of Dr. Sidney R. Garfield: The Visionary Who Turned Sick Care into Health Care. Appendix 2. A Report on Permanente's First 10 Years. Oakland and Portland: The Permanente Press; 2009.
5. Collen MF. History of the Kaiser Permanente Medical Care Program. An oral history conducted in 1986 by Sally Smith Hughes. Regional Oral History Office, The Bancroft Library, University of California, Berkeley; 1988.

6. Smilie JG. Can Physicians Manage the Quality and Costs of Health Care? The Story of The Permanente Medical Group. McGraw-Hill, Inc.; 1991.

7. Collen MF. Computer Medical Databases: The First Six Decades (19502010). Springer-Verlag London Limited; 2012.

8. Lindberg DA, Ball MJ. Morris F. Collen at 100: a tribute to "the father of medical informatics". Methods Inf Med. 2013:52(5):371-373.

9. Roemer BM, Azevedo T, Blumberg B. Looking at graduate medical education through a different lens: a health care system's perspective. Acad Med. 2015;90(9):1231-1235.

10. Rasgon $\mathrm{S}$. The importance of graduate medical education for Permanente physicians, Kaiser Permanente and American medicine. Perm J. 2007;11(4):79-87.

11. Berkeley School of Public Health. History. Available at: http://sph. berkeley.edu/school/history. Accessed November 11, 2016.
Advances in Medical Education and Practice

\section{Publish your work in this journal}

Advances in Medical Education and Practice is an international, peerreviewed, open access journal that aims to present and publish research on Medical Education covering medical, dental, nursing and allied health care professional education. The journal covers undergraduate education, postgraduate training and continuing medical education

\section{Dovepress}

including emerging trends and innovative models linking education, research, and health care services. The manuscript management system is completely online and includes a very quick and fair peer-review system. Visit http://www.dovepress.com/testimonials.php to read real quotes from published authors. 